\section{Australian Forestry Highlights}

\author{
By P. J. B. DUFFY and R. F. SHEPHERD
}

"The Australian Forestry Council

. . . deserves special study in Canada"

Canada Department,

of Fisheries and Forestry,

Ottowo.

O.D.C. 904: (94)

Canada Department

of Fisheries and Forestry,

Colgary, Alberto.

\section{Abstract}

Only four per cent of Australia is suitable for commercial forestry. The remainder is open woodland, scrub, grassland, and desert. Eucalyptus is the dominant native genus, many species of which are highly valuable. Pinus radiata dominates the planted forests which are being planted at a rate sufficient to overcome a deficiency of softwoods by the year 2000. The plantations are managed intensively; soil fertilization and frequent thinnings are standard operations. High yields are obtained from $\mathrm{P}$. radiata but the lack of diver. sification increases the risks from introduced insect and disease pests. Fire hazard conditions are often extreme in both planted and indigenous forests.

\section{Résumé}

\section{Les faits saillants de la foresterie australienne}

Les forêts commerciales de l'Australie ne couvrent que quatre pour cent du territoire, le reste étant prés-bois, broussailles, prairies et déserts. Les Eucalyptus sont les arbres forestiers indigènes les plus importants et les plus précieux. Dans les plantations, qu'on aménage à fond (éclaircies, engrais, etc.), on fait surtout pousser le Pinus radiata en vue de satisfaire la demande à compter de l'an 2000.

Côté planification générale forestière, on peut s'inspirer sur ce qui se passe là-bas. Touché par une balance commerciale très déficitaire, ce pays remonte la pente en plantant le Pinus radiata. Vu
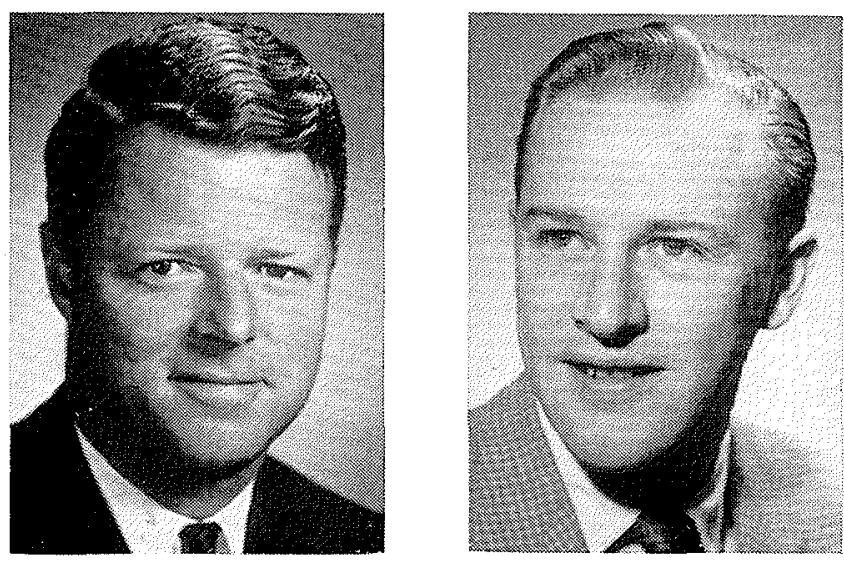

les tiraillements passés entre les autorités fédérales (dites du Commonwealth) et celles des états, on a mis sur pied un très viable organisme de travail appelé The Australian Forestry Council qui permet aux deux autorités de discuter les problèmes forestiers nationaux. Ceci se concrétise par des programmes prioritaires et par la coordination de la recherche. Les auteurs signalent les faits saillants se rapportant aux plantations et à la protection des peuplements. Pour terminer, il effleurent la foresterie de la Nouvelle-Guinée.

During the post-war period Australia's dependence on wood shipments from overseas has been growing. At present such imports cost the nation roughly $\$ 200,000,000$ per year. As a result new forestry programs are being initiated in an attempt to reverse the dependent situation by 2000 A.D. New and improved uses have been found for the indigenous eucalyptus and hundreds of square miles of Pinus radiata D. Don have been established over several states. The reduction of imports could be of importance to Canada as Australia is presently a major market for Canadian sawnwood and pulp and paper products.

The authors spent most of 1967 and part of 1968 in research work in land classification (Duffy) and in entomology (Shepherd) at the CSIRO Canberra laboratories. Their work permitted wide travel in Australia, New Zealand, and New GuineaPapua; the purpose of this article is to present some of their impressions of recent forestry developments in Australia. 


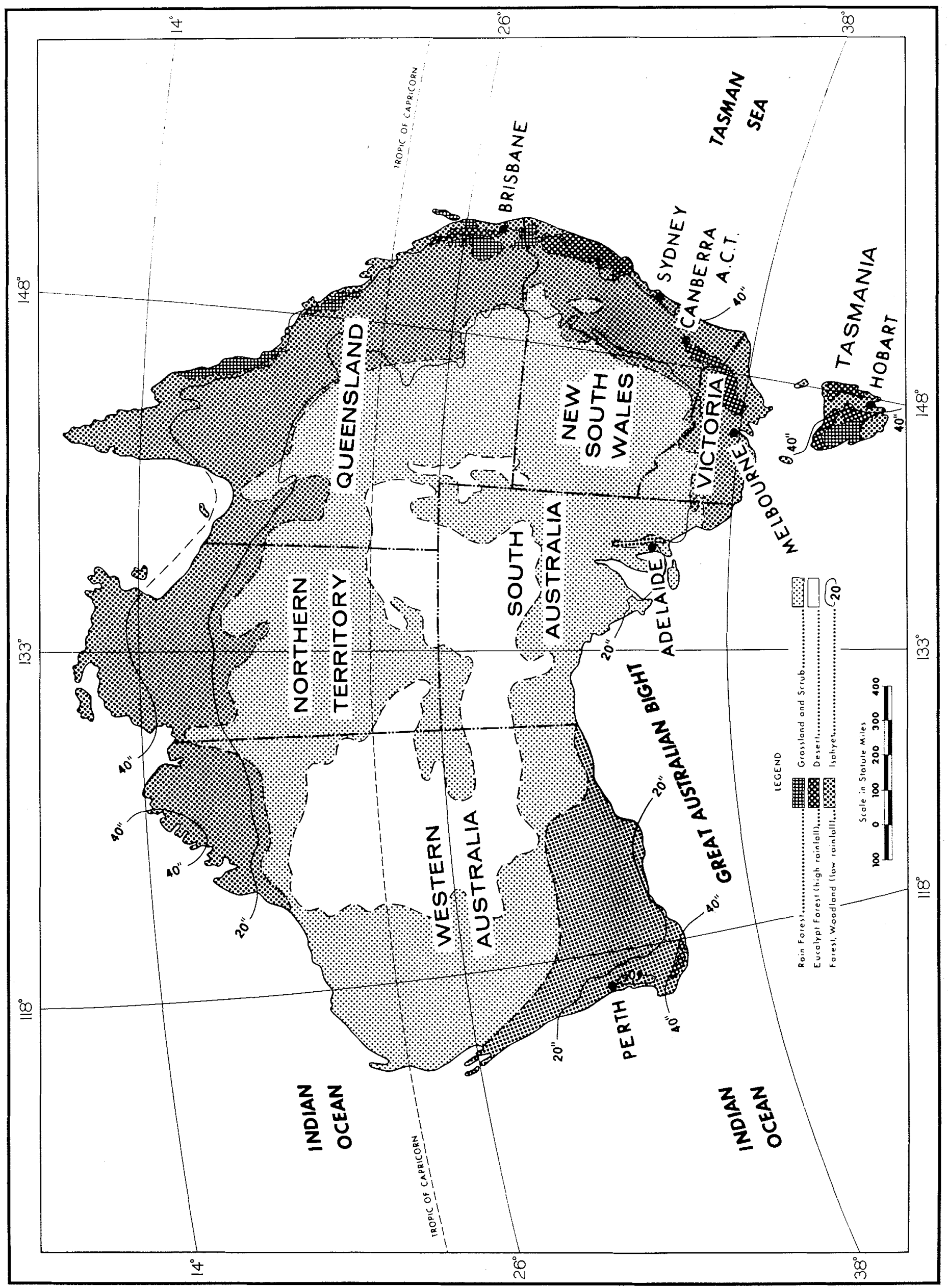

268 August 1969 The Forestry Chronicle 
Fig. I Vegetative and rainfall map of Australia. (Adapted from Anonymous 1962 and Bergamini 1965).

\section{The Forest and the Land}

The indigenous fauna and flora of Australia are unique and characterize a long period of ecological isolation. Most of the land is characterized by soils with low nutrient status and poor physical properties. Evaporation exceeds precipitation in most places, hence commercial forests are found only in Tasmania and along the southeastern and eastern fringe and in the southwest corner of the continent. Roughly 4 per cent of the land surface is capable of supporting these forests which are designated as Rain Forest and Eucalypt Forest (high rainfall) in Fig. 1. The high-rainfall vegetation of the southwestern corner of Australia has been isolated from the rest of Australia for thousands of years by a treeless plain (The Nullarbor).

The desert of the Australian centre covers about 14 per cent of the land surface; trees grow along water courses and in scattered scrub associations. Here the rainfall averages between 5 and 10 inches per year and prolonged droughts are common. The scrub acacia tree (mulga) sheds its leaves and persists through droughts and leafs out again following intermittent rains. The tree is not considered to be dead until the bark falls off.

The Australian desert is encircled by a large savannah-grassland type characterized by scrub acacia species and multiple-stemmed eucalyptus species (mallees). This type covers about 42 per cent of the continent. The rainfall there is between 10 and 20 inches per annum.

The remainder of the land surface is covered by savannah (open woodland) or dry sclerophyll iorest (forest, woodland, low rainfall in Fig. 1). Much of this type has been converted to natural or improved pasture for sheep and cattle grazing (Fig. 2)

The native forest in Australia contains over one thousand species of Eucalyptus and Acacia. Eu-

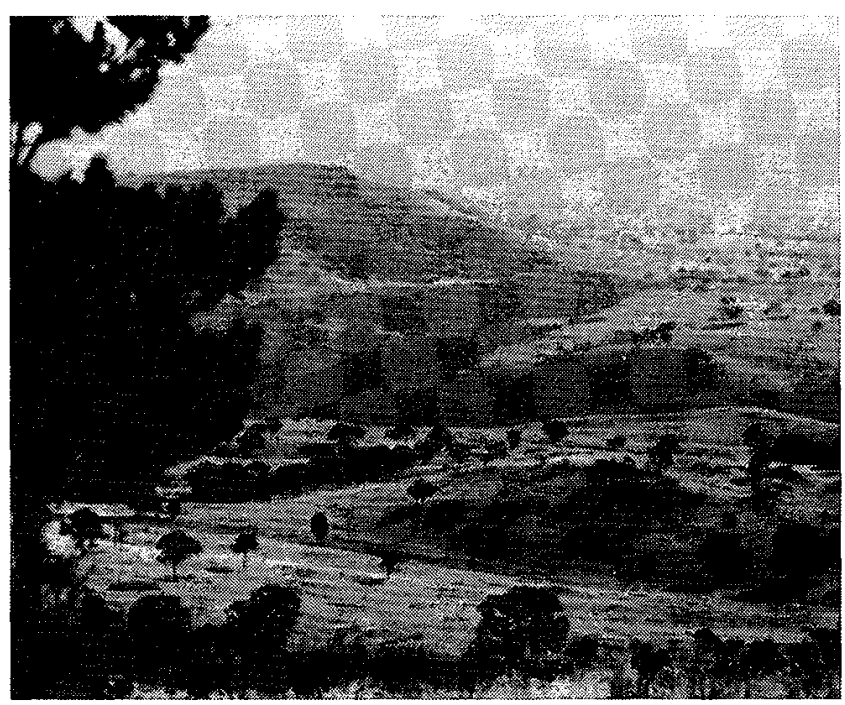

Fig. 2 Savannah, (open wodland) near Canberra, A.C.T. Pinus radiata plantations in middle distance. calyptus makes up about 95 per cent of the commercial indigenous forest. This genus has adapted to a wide range of habitats through the evolution of hundreds of species, each one adapted to a characteristic ecological environment. A significant factor in this evolution has been fire. The proliferation of species in the Eucalyptus genus, together with their ecological sensitivity has resulted in a major taxonomic problem for the Australian forester. It is often necessary to manage a specific commercial species within narrow ecological (and sometimes geographical) limits.

Highly productive wet sclerophyll forests are concentrated in the mountains of Tasmania, parts of Victoria and southern New South Wales (Fig. 3). Mountain ash (Eucalyptus regnans $F$. Muell) and alpine ash (Eucalyptus delegatensis) are found here as well as a wide variety of other useful hard-

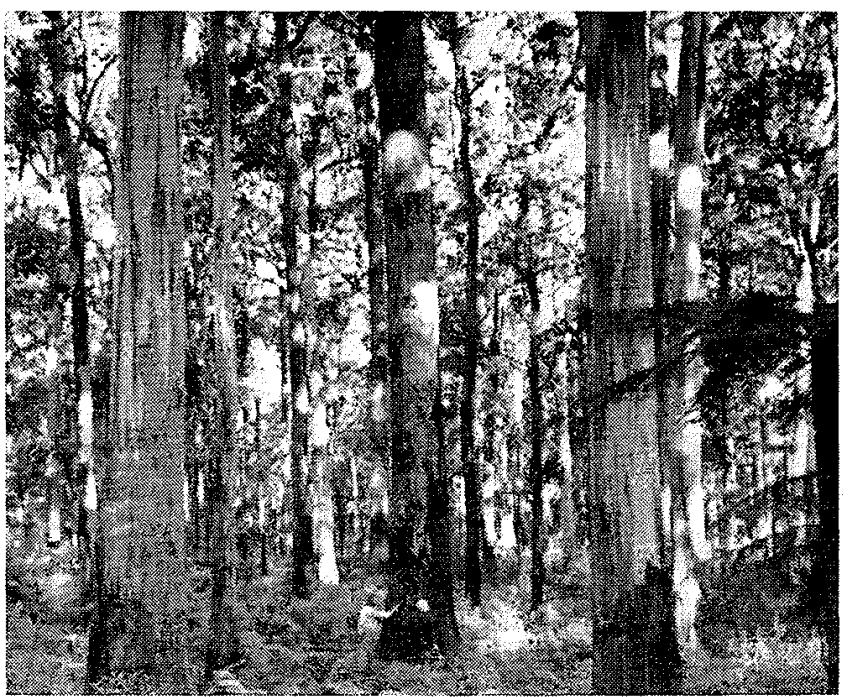

Fig. 3 Virgin mixed eucalyptus forest, New South Wales Highlands. Photo credit: N.S.W. Forestry Commission.

woods. The former is the world's tallest hardwood; dominant heights are 175 to 250 feet, with maximum heights of over 350 feet. This type, often mixed with a temperate rain forest, extends north into Queensland where it intergrades with a tropical rain forest spreading south from New Guinea. The tropical rain forest is a complex forest community with a large number of genera and species of trees. shrubs, lianas, and epiphytes.

The isolation of Southwestern Australia has contributed to the development of a unique and rich flora with over 6,000 species. The most valuable tree is the karri (Eucalyptus diversicolor F. Muell.) which grows up to 300 feet and supplies prime structural timber. The jarrah (Eucalyptus marginata $\mathrm{Sm}$.), another commercial species, is resistant to termites, suitable for construction, poles, piling and railroad ties and even sliced veener.

The remaining important component of vegetation in Australia is a temperate rain forest dominated by Nothofagus sp. This forest occurs at high elevations in eastern continental Australia, western Tasmania, and New Guinea. Nothofagus has little commercial use but is valuable for watershed protection. 
The E. regnans forest in Tasmania and Victoria are under relatively intensive management. Underbrush associated with the species is very heavy and must be removed prior to restocking. Twenty to thirty per cent of the brush is felled and dried at least three months beforehand to provide fuel for burning. Aerial seeding is scheduled immediately after the burn; if seeding is delayed to six months, the competition from new underbrush would prohibit tree establishment

The forest products industry is important in the Australian Territories of Papua and New Guinea. Until recently the industry has been mainly extractive with the removal of high-value tropical hardwoods. In high rainfall forests the average number of merchantable stems per acre is 3 or 4 . Sawmills and veneer plants have recently been established in the Klinkii pine (Araucaria hunsteinii) stands at Bulolo in the New Guinea highlands. Here the trees grow to 250 feet with diameters of 36 to 48 inches.

Plantations of teak are being established in low rainfall areas north of Port Moresby in Papua. To date the Department of Forests has planted about 2,000 acres. The stands are thinned at 7 years of age and the value of the thinnings pays for the planting costs three times over (Fig. 4). The expected annual income from teak plantations in this area is roughly $\$ 200$ per acre.

\section{Plantation Forestry}

The first exotic plantations were established in Australia about 1876. A wide variety of coniferous and deciduous species from overseas were planted, including pines, Douglas fir, elm, ash, oak and poplar. Pinus radiata from Monterey Bay, California

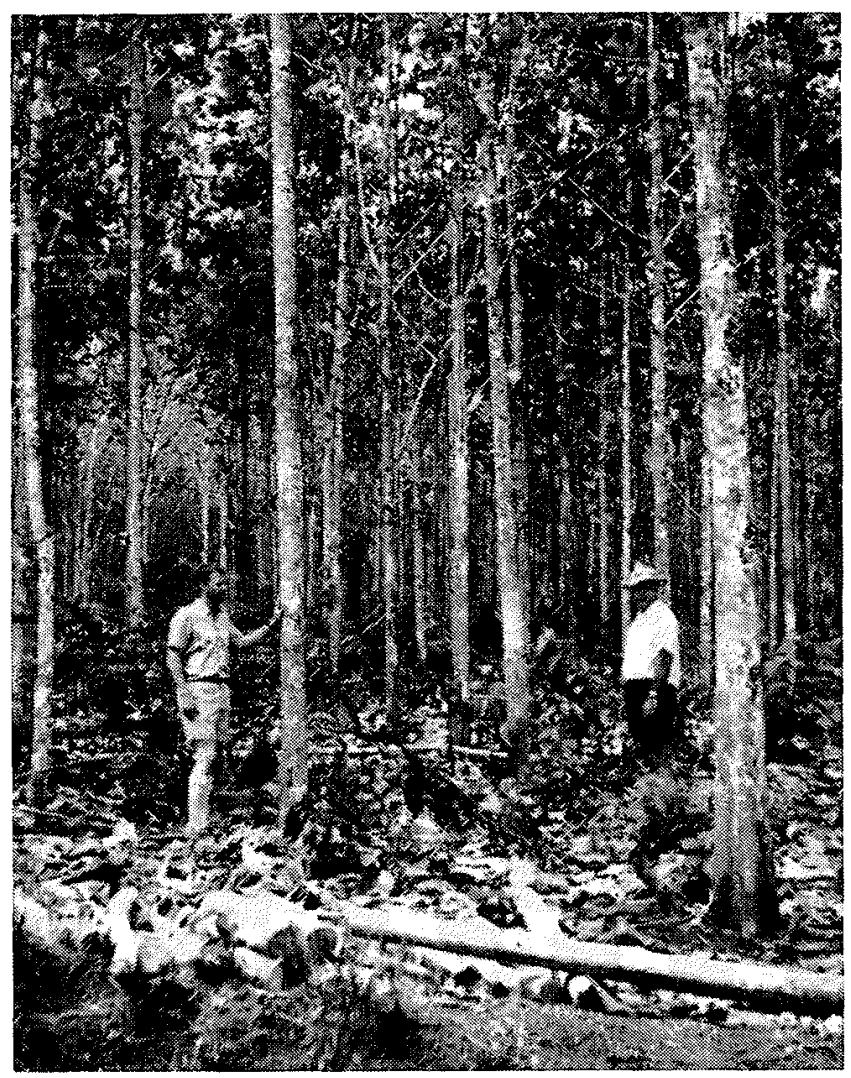

Fig. 4 Seven-year old thinning in teak, Port Moresby, Papua.

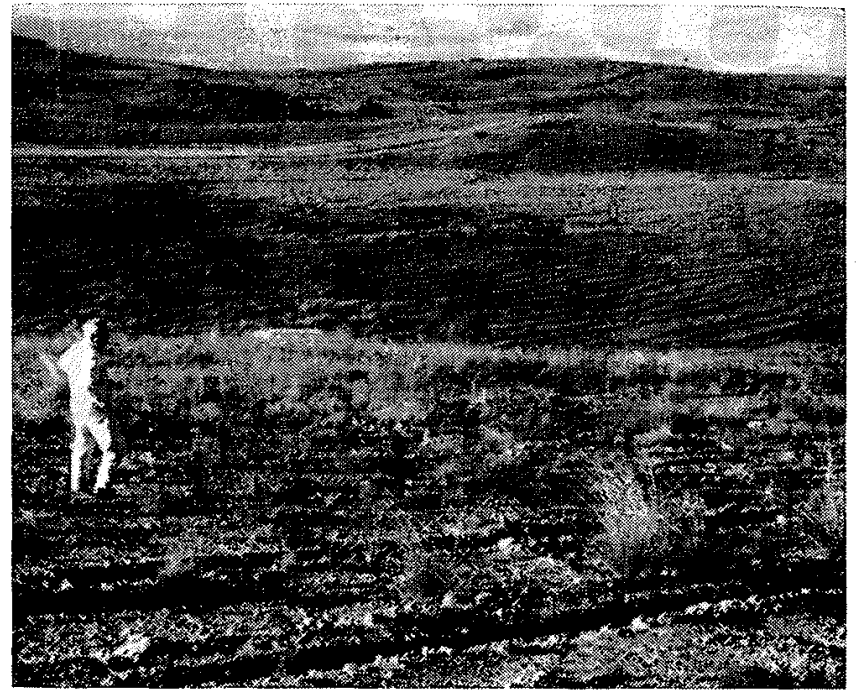

Fig. 5 One-year old Pinus radiata on deep ripped marginal pasture land, near Canberra, A.C.T.

exhibited extraordinary growth and subsequently an accelerated plantation program was developed in several states. In 1967 the Australian softwood estate was about 754,100 acres and the planting rate target was 75,000 acres per year (Jacobs 1968)

Pine plantations are concentrated at Mount Gambier, South Australia where upwards of 225 square miles are planted to $\mathbf{P}$. radiata and other pines and at Tumut, New South Wales. Extensive plantations have also been established in Victoria, the Australian Capital Territory and in Queensland. In many cases the stands have been established on degraded sheep grazing land, or on pasture land which has been dominated by pasture weeds such as the serrated tussock grass.

Early pine plantations were installed on unprepared sites; later deep ripping was practised (Fig. $5)$; and in recent years fertilizer has been added at the time of planting. The trees are planted during winter using the slit planting method. A "Lowther" treeplanting machine is employed on the sites which are clear of slash and which have suitable topography. The common initial spacing is 8 by 8 feet on the better sites and 9 by 9 feet on the poorer and drier sites (Forestry and Timber Bureau, 1957). Stands are thinned at 15 years and at 5 year intervals thereafter up to a final cut at 40-50 years (Fig. 6).

Land selected for plantations in Australia has a high capability by Canadian standards. This is primarily because of the long growing season which usually exceeds nine months. On a 3,300 square mile area in the Southern Tablelands of New South Wales and the Australian Capital Territory, it was estimated that on the best sites in high rainfall country (above 40 inches per annum) the mean dominant height for $\mathbf{P}$. radiata plantations at 20 years would be 110 feet and the mean annual increment (40 years rotation) would be up to $400 \mathrm{cu}$. ft. per acre (Gunn et al. 1969). An average Australian site index for $\mathbf{P}$. radiata (20 years) has been estimated at 73 feet and the comparable m.a.i. estimate is 250-350 cu. ft. per acre (Scott 1960).

Research has shown that $\mathbf{P}$. radiata is a versatile 
tree, having a tolerance to drought and low soil nutrient levels. Because the tree does not harden off, it is capable of rapid growth following heavy rains during almost all seasons. Growth has been found to increase with increased rainfall but the upper limit of that correlation has not yet been established.

Forest soil fertilization has undergone considerable research and development in Australia. Many of the soils are low in phosphorus, nitrogen, zinc and other major and minor nutrient elements. A favourable tree growth response is recognized primarily to phosphate and to a lesser degree to nitrogen fertilizers (Keay, Turton, and Campbell 1968; Gentle, Bamber, and Humphreys 1968), but further work is required to establish the correct

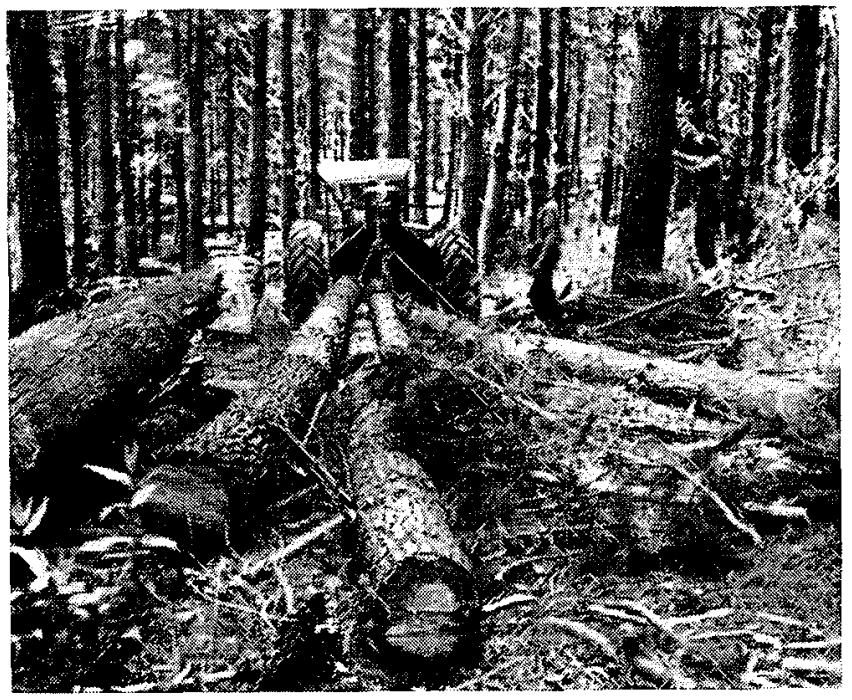

Fig. 6 Logging second thinnings from 20-year old Pinus radiata plantation, yield is about $1,500 \mathrm{cu}$. ft./acre. Photo credit: N.S.W. Forestry Commission.

levels and forms of fertilizer application. At present most new plantation sites are fertilized at the time of planting. In New South Wales, an effort is being made to appraise site (lithology, drainage, rainfall and nutrient conditions) on new plantation areas and to prescribe a specific soil amendment at the time of planting.

Site studies in the Mount Gambier area show that second rotations of pure pine stands on podsolized sands on old dune complexes are markedly less productive than the first rotation, the average reduction being about 25 per cent. Hamilton (1965) indicated that on these coarse-textured soils there are differences in nutrient cycling, exchange reactions, and physical properties of sandy soils depending on the type of vegetative cover. It is apparent that the conversion of eucalyptus types to pure pine stands does develop special ecological problems. The cause of the site degredation at Mount Gambier is the subject of several continuing research projects.

\section{Forest Protection}

In some forest types the accumulation of litter is very rapid and constitutes a severe fire hazard. Periodically extremely dry conditions develop in some localities with resultant holocausts and ex- tensive damage. Such a catastrophe occurred near Hobart, Tasmania in February, 1967 when a major fire swept over an estimated 1,000 square miles in about four hours, destroying 1,200 houses, killing over 50 people and resulting in damage to property estimated at $\$ 35,000,000$.

Many eucalyptus tree species have a tolerance to fire; and following severe burns epicormic shoots develop through the burned bark. In a few years a new crown replaces the old one. Damage is restricted to growth loss and sometimes to a small timber degrade because of resin pocket formation. Some species of eucalyptus shed great volumes of bark and oil-bearing leaves, providing fuel for intense fires (Fig. 7). To reduce hazard, foresters practise control burning by using slow moving ground fires in the winter.

Important insect and disease problems are associated with the extensive plantations of $\mathbf{P}$. radiata. Here the lack of diversification of tree species and a susceptibility to introduced pests are problems. A wood wasp (Sirex noctillio) and its associated fungus has caused considerable damage to $\mathbf{P}$. radiata in New Zealand, Tasmania and Victoria. Fortunately this insect selects weaker trees and low populations of Sirex can act as a thinning agent, but in high numbers Sirex may decimate a stand (Gilmour 1965, Coutts 1965). Dothistroma pini is a needle rust which appeared recently in New Zealand defoliating large areas and causing severe growth losses. This disease could threaten Tasmanian plantations but in continental Australia spread is likely because of the arid climate. Despite these risks foresters continue planting pure stands of $P$. radiata because of the superior yields and because of the additional costs required to develop a diversified forest.

\section{Forest Authorities}

Most forest lands in Australia are owned by the States. The State Forestry Commissions control the cutting of timber on all Crown lands but there is no Government control over forests on private land except where there is a high risk of erosion.

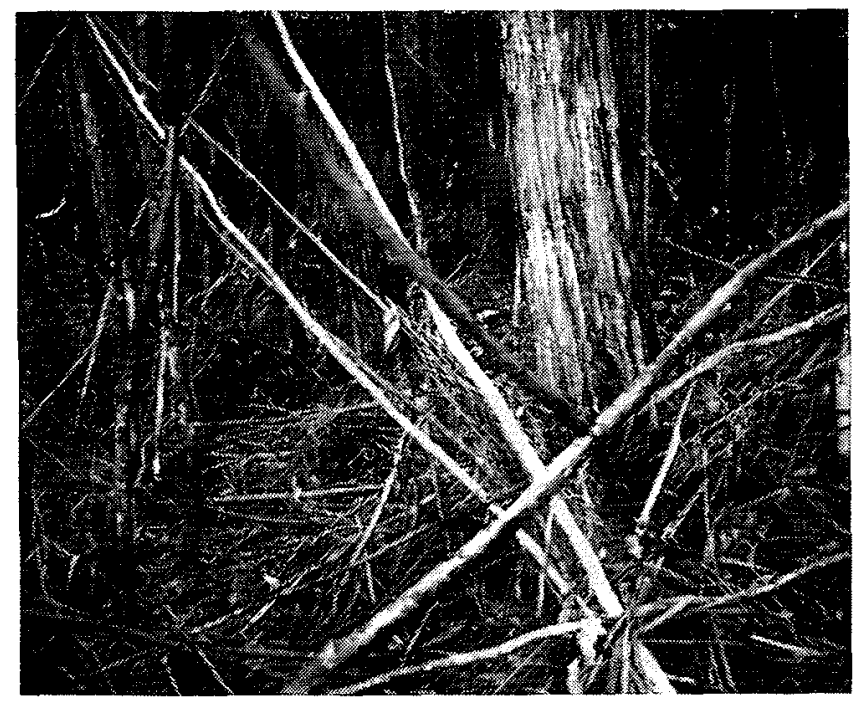

Fig. 7 Accumulation of bark and debris in a stand of $\mathbf{E}$. regnans in Tasmanio. 
The management and regeneration of forests on private lands are the responsibility of the company concerned, but the appropriate silvicultural practises are specified by the governmental forest authority (Slinn 1964).

The Commonwealth (Federal) Government is primarily in a research and advisory role as set out in the Forestry and Timber Bureau Act. The Forest Research Institute has its headquarters at Canberra, A.C.T., and there are five regional research stations. Other sections of the Forestry and Timber Bureau include offices of the Director-General and of Timber Supply Economics. Recently the Australian Forestry School was transferred from the Forestry and Timber Bureau to the Australian National University. Forest products research is carried out by the federally sponsored Commonwealth Scientific and industrial Research Organization.

The Australian Forestry Council is a national advisory body on forestry matters comprising the Ministers of all State and Commonwealth Governments (Jacobs 1965). It provides an efficient forum for the exchange of information and viewpoints among forestry authorities, and as such, deserves special study in Canada. The Council meets regularly to deal with co-ordination of research and with problems affecting the establishment, development, management, and protection of all forests and the utilization of forest products. It formulates and recommends policies to meet the domestic and export requirements for timber and other forest products.

At the inaugural meeting of the Council in August 1964, it was agreed that Australia should aim for an overall planting rate of softwoods of 75,000 acres per year. If the rate is maintained, Australia could become self-sufficient in softwood timber by the year 2000 (Jacobs 1968). Economic studies are underway to determine the type of lands that can be profitably converted into softwood production (Lewis 1967).

The Council considers the following matters to be of national importance:

1. The need to increase productivity in native forests by means of more intensive silvicultural treatment.

2. The need for better control of wild fire in forests, and of bushfires generally, by means of fuel

\section{References}

ANONYMOUS, 1962. Forest trees of Australia. Australia Forestry and Timber Bureau, $230 \mathrm{pp}$.

BERGAMINI, D, 1965. The land and wild-life of Australia. Time Inc. $198 \mathrm{pp}$

COUTTS, M. P. 1965. Sirex notillio and the physiology of Pinus radiata. Aust. Forestry and Timber Bureau Bull. 41.

FORESTRY AND TIMBER BUREAU, 1957. Exotic forest trees in the Australian Capital Territory. Commonwealth Forestry and Timber Bureau. 7th British Commonwealth Forestry Conference, Australia and New Zealand, 1957.

GENTLE, S. W., R. K. BAMBER and F. R. HUMPHREYS. 1968. Effect of two phosphate fertilizers on yield, financial yield, and wood quality of radiata pine. For. Sci. 14: 282-286.

GILMOUR, J. W. 1965. The life cycle of the fungal symbiont of Sirex noctillio. New Zeal. J. For. 10: 80-89.

GUNN, R., R. W. GALLOWAY, R. STORY, P. J. B. DUFFY, G. YAPP, and J. R. McALPINE. 1969. Lands of the Queanbeyan Shoalhaven Area, Australian Capital Territory reduction (control burning, including aerial control burning), coupled with improved fire detection methods, use of water bombing with chemical fire retardants, and improved fire weather forecasting.

3. The encouragement of afforestation by private enterprise.

4. The loss of productivity in second generation exotic pine plantations.

5. Quarantine problems associated with the importation of forest products.

An important matter which recently required the attention of the Council was the development of separate agreements with many States for the export of eucalyptus wood pulp chips to Japan. A total export of up to 2 million tons of green chips per annum is anticipated over periods of ten to fifteen years. State members of the Council requested that the Commonwealth Government coordinate these projects. Licenses are now granted only if the Commonwealth is satisfied that the sale price is adequate to cover costs of production, royalty or stumpage to the forest owners (usually the State Government), and forest regeneration and management. Satisfactory steps to develop further processing (i.e. pulp manufacture) in Australia must also be taken within seven to ten years.

The Council is an advisory body without executive powers, but as a Ministerial Council its recommendations carry considerable weight with Commonwealth and State Governments. The Commonwealth and State Government Departments work up Council recommendations with appropriate submissions and put these up for decision by the Commonwealth or State Minister.'

The effectiveness of this Council is illustrated by the positive action taken to accelerate the planting of softwoods to meet set goals. The objective is to make Australia self-sustaining in wood supplies within 30 to 40 years, an import factor in Canada's future markets. At present Canada is the largest supplier of both sawnwood and pulp and paper products to Australia (Jacobs 1968). Owing to Australia's ambitious program Canada stands to lose a customer presently buying $\$ 42$ million worth of wood products annually.

${ }^{1}$ Cree, C. S. Forestry and Timber Bureau, Canberra. Personal cammunicotion. December, 1968.

and New South Wales. C.S.I.R.O. Land Research Series No. 24. Melbourne.

HAMILTON, C. D. 1965. Changes in the soil under Pinus radiata. Austral. For. 29: 275-289.

JACOBS, M. R. 1965. The establishment of the Australian Forestry Council. Comm. For. Rev. 44: 92-96.

1968. The sources and use of forest products in Australia. Comm. For. Rev. 47 (3), 185-199.

KEAY, J., A. G. TURTON, and N. A. CAMPBELL. 1968. Some effects of nitrogen and phosphorus fertilization of Pinus pinaster in Western Australia. For. Sci. Vol. 14, No. 4, pp. 408-417.

LEWIS, N. B. 1967. Economic aspects of agriculture and afforestation on comparable lands. Australian For. 31 (1): 3-9.

SCOTT, C. W. 1960. Pinus Radiata. FAO Forestry and Forest Products Studies Publ. 14. $328 \mathrm{pp}$.

SLINN, R. J. 1964. Forest authorities and related legislation in Australia. Australia Forestry and Timber Bureau Leaflet No. 88. 